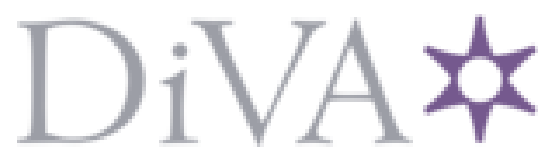

http://www.diva-portal.org

\title{
Postprint
}

This is the accepted version of a chapter published in Transcultural Identities in Contemporary Literature.

Citation for the original published chapter:

Zamorano Llena, C. (2013)

Transnational Movements and the Limits of Citizenship: Redefinitions of National Belonging in Joseph O'Neill's Netherland.

In: Gilsenan Nordin, Irene; Hansen, Julie; Zamorano Llena, Carmen (ed.), Transcultural Identities in Contemporary Literature Amsterdam: Rodopi

N.B. When citing this work, cite the original published chapter.

Permanent link to this version:

http://urn.kb.se/resolve?urn=urn:nbn:se:du-10707 


\section{Transnational Movements and the Limits of Citizenship Redefinitions of National Belonging in Joseph O'Neill's Netherland ${ }^{1}$}

\section{Carmen Zamorano Llena}

So we beat on, boats against the current, borne back ceaselessly into that past. $^{2}$

Londoners remain in the business of rowing their boats gently down the stream. ${ }^{3}$

In the last two decades there has been an abundance of studies, especially in the fields of political science and sociology, on current redefinitions of citizenship, belonging, sovereignty, and the nation-state. ${ }^{4}$ As various critics note, there is a dominant belief, despite voices to the contrary, that the role of the liberal nation-state is increasingly diminished, on the one hand, by the forces of globalisation which contribute to a shift in power from the national to the supranational, and on the other, by the increasing pluralisation of society due to intensified migration flows. ${ }^{5}$ These factors are regarded as crucial in originating a 'crisis of national identity' and the rise of a conservative turn in definitions of national belonging, which is often expressed in what Gerard Delanty, in the context of 1990s Europe, identifies as a new nationalism that "feeds off social insecurity." In the American context, this sense of social insecurity characterised the aftermath of the terrorist attacks on 11 September 2001, which in turn propitiated a conservative shift in definitions of communal belonging, and made issues of national identity one of the central themes, not only of political and sociological studies, ${ }^{7}$ but also of post-9/11 fiction. ${ }^{8}$ In this

1 I would like to acknowledge the financial support of the Swedish Research Council (Vetenskapsrådet) for the completion of this essay (project reference number: 2010-1820).

$2 \quad$ F. Scott Fitzgerald, The Great Gatsby (1925; Harmondsworth: Penguin, 1994): 188.

3 Joseph O’Neill, Netherland (2008; London: Harper Perennial, 2009): 172.

$4 \quad$ See, for example, Christian Joppke's Challenge to the Nation-State: Immigration in Western Europe and the United States (Oxford: Oxford UP, 1998); Immigration and the Nation-State (Oxford: Oxford UP, 1999); Citizenship and Immigration (Polity, 2010); and Yasemin Nuhoglu Soysal's Limits of Citizenship (Chicago IL: U of Chicago P, 1995).

5 Ruud Koopmans \& Paul Statham, "Challenging the Liberal Nation-State? Postnationalism, Multiculturalism, and the Collective Claims Making of Migrants and Ethnic Minorities in Britain and Germany," American Journal of Sociology 105.3 (1999): 652.

$6 \quad$ Gerard Delanty, "Beyond the Nation-State: National Identity and Citizenship in a Multicultural Society -A Response to Rex," Sociological Research Online 1.3 (1996): n.p., http://www.socresonline.org.uk/1/3/1.html (accessed 9 October 2011).

7 See, for example, Richard Crockatt's America Embattled: 9/11, Anti-Americanism, and the Global Order (London: Routledge, 2002), Mary L. Dudziak's September 11 in History: A Wathershed Moment? (Durham NC: 
context, Joseph O'Neill's novel Netherland (2008) offers a timely reflection on identity and communal belonging which provides an alternative to the conservative tone of the post-9/11 American political discourse. This conservative political discourse was not new, however, since it echoed the ethnocultural Americanism of the socio-political context of 1920s and 1930s America. O'Neill's Netherland points to the connection between these two time periods in his reaccentuation of F. Scott Fitzgerald's classic novel The Great Gatsby (1925), a novel that recent literary criticism has analysed within the context of the ethnocultural Americanism that figures in the setting of Scott Fitzgerald's fictional text.

The Great Gatsby is the swan song of the American dream. Narrated as a first-person recollection by Nick Carraway, an observer of the archetypal self-made man Jay Gatsby's rise and fall, the novel is generally regarded as "a dramatization of the betrayal of the naïve American dream in a corrupt society," or, more generally, as "the unending quest of the romantic dream, which is betrayed in fact and yet redeemed in men's minds." 10 However, literary criticism produced in the last fifteen years has highlighted evidence of ethnocultural Americanism $^{11}$ in this classic text, especially as represented by Tom Buchanan and a veiled

Duke UP, 2003), Sebastian J. Westphal's American National Identity After September 11 (Berlin: Wissentschaflicher Verlag Berlin, 2007), Derek Rubin \& Jaap Verheul's American Multiculturalism After 9/11 (Amsterdam: Amsterdam UP, 2009).

$8 \quad$ For a detailed analysis of this fiction, see Kristiaan Versluys' Out of the Blue (New York: Columbia UP, 2009) and Richard Gray's After the Fall: American Literature since 9/11 (Malden MA: Wiley, 2011). More recently, the scholarly journal MFS: Modern Fiction Studies has dedicated an issue, published in Autumn 2011 (57.3), to post-9/11 fiction.

$9 \quad$ Robert Ornstein, "Scott Fitzgerald's Fable of East and West," College English 18.3 (1956): 139.

10 Ornstein, "Scott Fitzgerald's Fable," 139.

11 According to Rogers M. Smith, the origins of this ethnocultural Americanism are to be found in the times following the Revolutionary era, when "many American leaders deliberately promoted the popular notion that Americans had a distinctive character, born of their freedom-loving Anglo-Saxon ancestors and heightened by the favourable conditions of the new world." Even before any theoretical elaborations of this ideology were produced, Smith argues that many Americans based their identification with the new independent nation, not on the liberal principles of the American Creed, inspired by human rights and religious tolerance, but on a more reductionist sense of collective identity:

From the outset of the nation many Americans chiefly identified membership in their political community not with freedom for personal liberal callings or republican self-governance per se, but with a whole array of particular cultural origins and customs -- with northern European, if not English, ancestry; with Christianity, especially dissenting Protestantism, and its message for the world; with the white race; with patriarchal familial leadership and female domesticity; and with all the economic and social arrangements that came to be seen as the true, traditional "American way of life." (Rogers M. Smith, "The 'American Creed' and American Identity: The Limits of Liberal Citizenship in the United States," The Western Political Quarterly 41.2 (1988): 234). 
suggestion of Gatsby's Jewish origins and associations. ${ }^{12}$ The nativism underlying the novel, which goes against the traditionally liberal democratic values of the 'American Creed,' is understood as a literary representation of the fears experienced in some conservative, privileged sectors of American society in the 1920s, where it was felt that the crucial economic and social changes of those years posed a menace to their sense of identity. ${ }^{13}$ In his study regarding the limits of liberal citizenship as reflected in the civic laws implemented at the end of the nineteenth century, Rogers M. Smith claims that in times of "great economic and social change, the most influential segments of the American populace [do not feel that they can] meet their longings for a secure sense of civic identity and for protection of the existing social order by uniting around the 'American Creed'," and, consequently, they tend to adopt non-liberal ideals in defence of their privileges, which they, in turn, incorporate into their discourse of American national identity. ${ }^{14}$

Smith's explanation for the origins of this conservative turn in constructs of national identity and, consequently, of national belonging in the form of formal citizenship, generally defined as membership in a nation-state as regulated by laws and policies, ${ }^{15}$ also accounts for the

12 See Jeffrey Louis Decker, "Gatsby's Pristine Dream: The Diminishment of the Self-Made Man in the Tribal Twenties," NOVEL: A Forum on Fiction 28.1 (1994): 52--71; Walter Ben Michaels, Our America: Nativism, Modernism, Pluralism (Durham NC: Duke UP, 1995); and Barbara Will, "The Great Gatsby and the Obscene Word," College Literature 32.4 (2005): 125--44. As Benjamin Schreier notes, "by highlighting the novel's interest in race and its role in the development of discourses that continue to administer the recognition of race and ethnicity in America, this new criticism [...] purports to rescue The Great Gatsby from the sentimental attractions of a universalized, imperial American identity" (153). Other significant authors whom Schreier quotes as adopting this new critical approach to The Great Gatsby are Washington (1995), Nies (2002), Goldsmith (2003), and Thompson (2004). Benjamin Schreier, "Desire's Second Act: 'Race' and The Great Gatsby's Cynical Americanism," Twentieth Century Literature 53.2 (2007): 153--81.

13 Barbara Will summarises some of the socio-historical changes that account for the peak in nativist understandings of Americanness in the 1920s: "This is a moment in which American isolationist fervor is at its peak, a moment in which fears over 'the expanded power of the alien' are being openly expressed in political, intellectual, and literary forums" (134). This is the time of the Immigration Restriction Act of 1921, the more restrictive Johnson-Reed Immigration Act of 1924, and of the cry "America for the Americans." The latter act was aimed at limiting the number of Southern and Eastern European immigrants, who had been arriving in the United States in increasing numbers since 1890, and to stop the immigration of East Asians and Asian Indians. In the literary sphere, Charlotte Perkins Gilman, agitator for women's rights, expressed her concern in 1923 about a possible excess in the acceptance of immigration to America in an essay entitled "Is America Too Hospitable?" (Will 134). As Gary Y. O'Kihiro notes, these were manifestations of the fear of the white American majority, who felt their privileges threatened by growing "urbanization, immigration, poverty, class conflict, deep divisions between North and South, East and West, and the depressions of 1873 and 1893" (Gary Y. O'Kihiro, Margins and Mainstreams: Asians in American History and Culture (London: Routledge, 1994): 31).

14 Rogers M. Smith, “'American Creed' and American Identity: The Limits of Liberal Citizenship in the United States," The Western Political Quarterly 41.2 (1988): 227.

15 Stephen Castles \& Alastair Davidson, Citizenship and Migration: Globalization and the Politics of Belonging (New York: Routledge, 2000): 127. 
new conservative turn that is manifest in some current cultural analyses of American national identity. Thus, in his contentious text The 50\% American: Immigration and National Identity in an Age of Terror (2005), political psychologist Stanley A. Renshon considers the pernicious influence of both recent migration and transnationalism on definitions of American national identity in a post-9/11 context, and concludes: "If multiculturalism represents the leading domestic challenge to an American national identity, international cosmopolitanism and transnationalism represent its global face." 16 He contends that allegiance to the liberal democratic ideals of the 'American Creed' is not sufficient to ensure the cohesion of the American nation, and that a psychological attachment and emotional bonding, in the form of patriotism, to the nation are essential in order to guarantee the healthy permanence of a unified American national identity. Renshon argues that for the American motto -- "E pluribus unum" -to work, new migrants must adopt the psychological traits of the American people, which he identifies as deriving from the American pioneers: ambition, courage, self-reliance, independence, and forward-looking pragmatism. According to Renshon, "these elements of American national psychology constitute the psychological center of gravity for American national culture." 17 In response to accusations that this definition of American national identity "mask[s] a demand to conform to [...] 'Anglo/White culture'," Renshon responds that "the genius of American culture, psychology, and identity is that over time they have become decoupled from ethnicity, religion, and even race." 18

Renshon's assumption of this neutralised American identity is connected with the official models of naturalisation that "presume that immigration consists of leaving one society and joining another,"19 thereby making a 'clean break' with the past and encouraging the newly naturalised individuals to look forward to their future as new American citizens. Thus, the formation of these new American citizen-subjects forces the erasure of "their histories and render[s] difference generic"; the new citizens' cultural difference is something to be exercised in their private sphere. ${ }^{20}$ The implicit ethnocultural Americanism identified in this model of naturalisation, and in Renshon's reflections upon the state of American national identity at the

16 Stanley A. Renshon, The 50\% American: Immigration and National Identity in an Age of Terror (Washington D.C.: Georgetown UP, 2005): 128.

17 Renshon, The 50\% American, 64.

18 The $50 \%$ American, 65.

19 Susan Bibler Coutin, "Cultural Logics of Belonging and Movement: Transnationalism, Naturalization, and U.S. Immigration Politics,” American Ethnologist 30.4 (2003): 509.

$20 \quad$ Coutin, "Cultural Logics of Belonging and Movement," 509. 
beginning of the twenty-first century, echo the conservative turn that characterised the 1920s and which underlies Fitzgerald's The Great Gatsby. In the current context, however, the challenge to the nation-state and traditional definitions of formal citizenship and collective identity posed by processes of globalisation and transnationalism are added to the ethnocultural division that characterised the aftermath of the 9/11 attacks in diverse societies both in the United States and beyond. ${ }^{21}$ It is in this context that the Irish-born, multicultural, and recently naturalised American writer Joseph O’Neill ${ }^{22}$ sets his novel Netherland, a text which has been associated with Scott Fitzgerald's classic work. ${ }^{23}$ However, whereas The Great Gatsby evokes a nostalgic look "ceaselessly into that past" the new world" 25 in the New York that the first Dutch sailors set eyes on four centuries earlier and which they named New Netherland, O’Neill engages critically with the present. Through this critical appraisal of contemporary America in his fictional text, O’Neill proposes a redefinition of collective and individual identity in a globalised context interspersed with transnational personal and public allegiances. The aim of this essay is to argue that O'Neill's text suggests that the redefinition of homogenising national belonging in this new transnational context is to be obtained by recognising what postcolonial critic Homi Bhabha has called the "difference 'within'., ${ }^{26}$ However, O'Neill's novel advances the view that this redefinition cannot be realised

21 Within the American context, for example, Jennifer Bryan's "Terror Town Jersey City: Cultural Trauma, Conflict, and Community after 9/11" analyses the redefinition of collective identity and the shifting nature of intergroup relationships for Arab Muslims and their neighbours in the working class area of Jersey City, New Jersey. (paper delivered at the American Sociological Association, http://www.allacademic.com/meta/p184715_index.html).

${ }_{22}$ As stated in the author's The Times profile, "O'Neill is the exotic creation of multiple cultural identities and, as he himself points out, none at all. His father was Irish, his mother Turkish, he grew up in Holland, speaks with a precise English accent and is now an American citizen" ("Profile").

23 See, for example, Michiko Kakutani's book review for The New York Times. In an interview with Katie Bacon, Joseph O'Neill also comments on similarities between The Great Gatsby and his novel Netherland. According to O'Neill, the plot is very similar, and "you have this charismatic gangster figure and this phlegmatic narrator." He identifies a crucial distinction between these two literary texts, however. Whereas The Great Gatsby is the story of the corruption of the American dream written on the premise of an intact America, Netherland is written on the premise that this intact America does not exist any longer. As O'Neill remarks: "there are forces -- including 9/11 and the globalization of the economy -- which have destroyed that premise and put an end to a hugely significant literary and cultural era in American life. I think the challenge for writers is to explore that and recognize it."

$24 \quad$ Fitzgerald, The Great Gatsby, 188.

$25 \quad$ The Great Gatsby, 187.

26 Homi K. Bhabha, The Location of Culture (London: Routledge, 1994): 13. In recent years, the work of Bhabha in relation to postcolonialism has been the object of criticism. One of the most relevant criticisms for the present essay is to be found in Michael Hardt and Antonio Negri's Empire (2000). Hardt and Negri have criticised Bhabha's work as being characteristically postcolonial in that it presents the worldview of a privileged class and is consequently in danger of remaining at the level of theory. As Huddart notes, they have also criticised what they 
solely on the basis of a hybridised definition of national identity. This essay contends that Netherland implies that the reconstruction of collective belonging requires the intertwined work of two different actors in the redefinition of the organic national community, namely, the narrative of the migrant communities that have traditionally integrated multicultural America, and the new transnational migrant whose ties are facilitated by new technologies and a globalised economy.

In The Location of Culture Homi Bhabha contends that organic national communities need to be redefined from the perspective of those occupying the "space of the beyond," 27 i.e. those minorities which the dominant narratives of communal identity have relegated to the margins of national culture. The effect of this process is not the emergence of "alternative stories of the excluded," 28 since this would merely represent a perpetuation of their exclusion. The aim, according to Bhabha, is to redefine national cultures so as to incorporate the narratives of the marginalised as an integral part of the national narrative. As Bhabha claims, "the Western metropole must confront its postcolonial history, told by its influx of postwar migrants and refugees, as an indigenous or native narrative internal to its national identity. ${ }^{, 29}$ In this regard, Bhabha's views of the renewed narrative of national identity converge with what literary scholar Richard Gray identifies as the necessary development of American literature in the aftermath of 9/11. In his seminal essay, "Open Doors, Closed Minds: American Prose Writing at a Time of Crisis," Gray analyses the literary production after the cataclysmic events of 9/11. He concludes that most of these texts are unable to deal with what he terms the "strangeness" that is becoming increasingly characteristic of the United States, that is, the transformation of the United States into "a border territory in which different cultures meet, collide, and in some instances collude with each other." ${ }^{30}$ As Gray notes, since the 1980s there have been an increasing number of

regard as the redundancy of the critique of binary oppositions in the contemporary context (Huddart 165). However, as Bhabha significantly points out in response to this criticism, the post-9/11 context, in which the polarisation of power and identities have become more obvious, has also made this critique of binary oppositions, fostered by concepts such as hybridity and Bhabha's emphasis on the culture of difference over a culture of diversity, highly relevant: "The aftermath of $9 / 11$ has, I believe, made even more urgent the '80s endeavour to think of issues relating to political and cultural difference beyond the polarities of power and identity" (Bhabha 2003 ADD PAGE NUMBER). It is in this sense that Bhabha's work is considered, in this essay, as providing a useful framework to analyse critically the issues of national identity in the post-9/11 context on which O'Neill's novel focuses.

27 Bhabha, The Location of Culture, 1.

28 The Location of Culture, 6.

29 The Location of Culture, 6.

30 Richard Gray, "Open Doors, Closed Minds: American Prose Writing at a Time of Crisis," American Literary History 21.1 (2009): 135. 
novels produced by the new migrants. ${ }^{31}$ These novels and the new, deterritorialised depiction of America that they offer, have gained central importance, especially after the events of $9 / 11$, by providing a model of how to redefine what constitutes the American narrative of identity after 9/11. ${ }^{32}$ Thus, these texts rewrite understandings of native American culture by showing how they are an integral part of, and "internal to [contemporary American] national identity."33

O'Neill is one of these new transnational migrant authors. His third novel, Netherland, "reaccentuates" 34 Scott Fitzgerald's The Great Gatsby, by modelling the narrative structure on this classic text and offering a different perspective on the American nation at a new moment of dramatic cultural, economic, and socio-political changes. The first-person narrative voice in Netherland is that of Hans van den Broek, a Dutch oil-futures analyst married to Rachel, an English lawyer. The couple is forced to move from their Tribeca apartment to the bohemian Chelsea Hotel due to the bombing of the World Trade Center. As their marriage begins to fall apart in the aftermath of 9/11, Rachel and their baby boy move back to London, while Hans stays in New York. He enters a period of transatlantic commuting to see his child, while trying to make sense of his life in New York. It is during this period that his unusual friendship with the first-generation migrant Chuck Ramkissoon develops. Much like Fitzgerald's Nick Carraway, Hans tells the story from the perspective of an observer, several years after he has returned to London and reunited with his wife and child. Through Hans' tale, the novel not only offers the story of two apparently dissimilar migrants, but it also provides evidence, as will be shown

31 Some of the authors and works of fiction that he points to as significant texts in this regard are Wayne Karlin's Lost Armies (1988) and Prisoners (1998), Lan Cao's Monkey Bridge (1997), Dao Strom's Grass Roof, Tin Roof (2003), and Chang-Rae Lee's Native Speaker (1995).

32 In response to Gray's essay, Michael Rothberg claims that whereas Gray's proposal stays firmly "on native ground," what is required is a "centrifugal literature of extraterritoriality" that shows "how US citizenship looks and feels beyond the boundaries of the nation-state, both for Americans and for others" (157--58). Although Rothberg's proposal is a valuable addition to Gray's, it still falls short of the possibilities offered by texts such as O'Neill's Netherland, since it does not consider the transnational turn in definitions of collective identity, including American national identity, and the challenges this poses to formal definitions of citizenship. These aspects, which are overlooked by Rothberg's analysis of Netherland, are regarded in this essay as crucial contributions made by this fictional text to debates on issues of citizenship and national belonging in the contemporary post-9/11, transnational context.

33 Bhabha, The Location of Culture, 6.

34 In his "Discourse in the Novel," Mikhail Bakhtin claims that "every age reaccentuates in its own way the works of its immediate past" (421). Richard Gray quotes Bakhtin to argue that post-9/11 novels should be characterised by "at the very least a radical reaccentuation" (134). The degree of "radical reaccentuation" in O'Neill's novel is arguably relative. However, his novel does significantly engage dialogically with The Great Gatsby, the key twentieth-century American novel that laments the disappearance of the American Arcadia as a consequence of the corrupting effects of the modern age. O'Neill transforms this lamentation into a perception of the new possibilities which have been opened for a more inclusive redefinition of Americanness as a result of historical changes in the aftermath of $9 / 11$, as well as the pressures of globalisation and transnationalism. 
below, of how their intertwined stories propound a new narrative of American national identity in the post-9/11 context.

As Salman Rushdie points out, "the migrant is not simply transformed by his act [of migration]; he transforms his new world," 35 and by doing so, becomes an integral part of the national narrative of the adopted country. In Netherland, this transformative enterprise is the main objective of the Gatsby-esque Trinidadian of South-Asian origins, Chuck Ramkissoon. This is symbolised by his project to reintroduce, and restore to its former glory, what he defines as "the first modern team sport in America," which is "already in the American DNA"; this sport is not, as might be expected, baseball or football, but cricket. ${ }^{36}$ Thus, the enterprise of 'reaccentuating' cricket as an American sport becomes a core symbol for the redefinition of American national identity in the post-9/11 historical context. As Ramkissoon notes in an email entitled "NOT AN IMMIGRANT SPORT," which he sends out to his electronic mailing list, this most quintessentially English and allegedly un-American sport was already played in New York in the 1770s: "it was a professional sport reported in all the newspapers [and] there were clubs all over the country" (98). Cricket was indeed popular in the United States in the mid-nineteenth century and stayed so until the end of that century, when its popularity began to decline sharply. As cultural critics Jason Kaufman and Orlando Patterson observe, it is only in recent years that this sport has started to regain some prominence in the States, "when new immigrants from the Caribbean and South Asia began arriving in North America in significant numbers."37 Despite the historical presence of the sport in America, dating from the time of the pioneers, cricket is as extraneous to the average American "as M'ikmaq hieroglyphs scratched on birch bark," as O’Neill, himself a passionate cricketer and member of the Staten Island Cricket Club, asserts in his review of the autobiography Beyond a Boundary (1963) by the Trinidadian C.L.R. James, a classic text on cricket and its colonialist implications. ${ }^{38}$ However, because of its apparent strangeness in the context of American national identity, cricket works as a powerful literary

35 Rushdie, Salman / ICA Video (Northbrook IL: Roland Collection of Films on Art, BBC, 1989), quoted in Richard Gray, "Open Doors, Closed Minds," 210.

$36 \quad$ Joseph O’Neill, Netherland (2008; London: Harper Perennial, 2009): 98. Further page references are in the main text.

37 Jason Kaufman \& Orlando Patterson, "Cross-National Cultural Diffusion: The Global Spread of Cricket," American Sociological Review 70.1 (2005): 83.

38 Joseph O'Neill, "Bowling Alone," review of Beyond a Boundary by C.L.R. James, The Atlantic Monthly (11 September 2007), http://www.powells.com/review/2007_09_11.html (accessed 13 February 2011). 
symbol for the redefinition of the national narrative from marginal(ised) spaces. ${ }^{39}$ Thus, by encouraging the American audience to face a blind spot in their tradition, Ramkissoon engages critically with American national culture and recovers an element to which the new migrant can relate. This is a past American tradition with which the new migrant identifies and which he can update, adopt, and adapt to the present circumstances of American cultural diversity.

In terms of its historical relevance, several reasons have been provided for the decline of cricket in the United States. However, one of the most compelling is that, although the sport was first introduced by working-class immigrants from the British Isles, ${ }^{40}$ by the end of the nineteenth century it had become an elite sport. As a reaction to the egalitarian ethos that encouraged the emergence of the nouveau riche, the 'old-money' elite turned to the gentlemanly and genteel ${ }^{41}$ game of cricket, as one of the "status-based activities with which to maintain their superior position in the social system. $" 42$ This separation from the popular sphere, which baseball quickly came to occupy, turned cricket into a rarefied activity which was soon superseded by tennis and golf as the new sports of America's wealthiest families. ${ }^{43}$ In the novel, however, the game as played in contemporary New York has symbolically returned to its egalitarian origins. Hans is invited, in a chance encounter with a taxi-driver called Umar, to join the cricket games regularly played in the boroughs of New York. Upon his arrival at Walker Park in Staten Island, Hans soon realises that he is the only white man amongst players of foreign origin, mostly from the West Indies, who, as he finds out subsequently, have more modest professional occupations than his own. Thus, "the first modern team sport in America" (98), which died out when

39 The use of cricket to examine redefinitions of national narratives of identity in a postcolonial and globalised context is also to be found in a recent and growing body of research in the field of social and cultural studies. A seminal text in this regard is Stephen Wagg's Cricket and National Identity in the Postcolonial Age: Following On (London: Routledge, 2005). As Wagg remarks, the main aim of his edited collection is to explore the role that cricket played in ex-British territories in the construction of "a new, independent national identity" (1). The transformation of cricket from a symbol of Englishness and the British Empire to a form expressing independent national identities in a postcolonial context resembles O'Neill's use of cricket as a form capable of symbolising the forging of a new sense of collective identity in post-9/11 America.

$40 \quad$ Kaufman \& Patterson, "Cross-National Cultural Diffusion," 97.

41 Significantly, the group of businessmen and entrepreneurs that invested their time and financial resources in turning baseball into the national sport is also responsible for the intentional misrepresentation of cricket as a "genteel game" (Spalding, quoted in Kaufman \& Patterson, 95). As Kaufman and Patterson argue, the star player and sports entrepreneur Albert G. Spalding "mischaracteriz[ed] the nature of English cricket, and English society more generally," but the crucial point is that Spalding's and other similar statements decisively contributed at that time to "a specifically North American perception of cricket" as gentle, genteel, conventional, decorous, and effeminate (96), which would eventually contribute to its virtual demise in the United States at the turn of the twentieth century.

$42 \quad$ Kaufman \& Patterson, "Cross-National Cultural Diffusion,” 98.

43 "Cross-National Cultural Diffusion," 99. 
confined to the American elite, has returned to its origins, namely, to being played by workingclass migrants, not from the British Isles, but from former British colonies. However, if the sport is to subsist, it needs to be adapted to the current circumstances of the geographical and historical context where it is played. Similarly, national identity, like the game of cricket, needs to adapt to the condition of the specific ground where it is played out, as suggested by Hans' reflections on the nature of the sport. As Hans tends to the field that Chuck Ramkissoon plans to turn into a cricket stadium, he reflects on the earthiness of cricket as opposed to the aerial game of baseball. He also notes how the cricketers have to adapt their game to the conditions of the terrain:

In baseball, essentially an aerial game, conditions are very similar from match to match, from stadium to stadium [...]. In earthly cricket, however, conditions may be dissimilar from day to day and from ground to ground. Sydney Cricket Ground favours spin, Hedingley, in Leeds, seam bowling. This differentness is not only a question of differing grass batting surfaces. There is the additional question of the varying atmospheric conditions -- humidity and cloud cover, in particular -- that [change] from time to time and from place to place and can dramatically affect what happens to a cricket ball as it travels from bowler to batsman. Likewise, soft and hard outfields will respectively preserve and roughen a ball. For all of its apparent artificiality, cricket is a sport in nature. (143--44)

Chuck is a shady character who, from very modest beginnings as a young new immigrant in America, has become naturalised and started a number of companies with somewhat unclear commercial aims. He is also a visionary who, moved by his motto "think fantastic," can intuit the transformative possibilities that the game of cricket contains, forcing its players to adapt to varying spatial and atmospheric conditions. Cricket is the lens through which Chuck observes post-9/11 America and which allows him to see the possibilities that the game offers to overcome the limiting Americanist definitions of national identity that dominated the sociopolitical context in the aftermath of the attacks. One of the effects of 11 September has been the reinforcement of past constructions of national identity on exclusive binary oppositions, whereby Arab Muslims have been turned into the new 'other,' thus weakening in practice a sense of formal citizenship based on liberal democratic values. ${ }^{44}$ As an alternative, Chuck vindicates a

$44 \quad$ Nadine Naber observes how the post-9/11 political discourse has made $9 / 11$ a turning point in the "histories of anti-Arab racism in the United States." Naber argues that this anti-Arab racism was already present, and that 9/11 has only brought this to the centre, with an intensification of 'Othering' representations of the Arab Muslim, where 'representations of 'terrorism' and 'Islamic fundamentalism' have increasingly replaced other representations (that is, the rich Arab oil sheikh and belly-dancing harem girls) and have become more fervently deployed in anti-Arab 
more productive, forward-looking way of adapting to the new circumstances. As Chuck explains to Hans:

[...] all people, Americans, whoever, are at their most civilized when they're playing cricket. What's the first thing that happens when Pakistan and India make peace? They play a cricket match. Cricket is instructive, Hans. It has a moral angle. [...] Americans cannot really see the world. They think they can, but they can't. I don't need to tell you that. Look at the problems we're having. It's a mess, and it's going to get worse. I say, we want to have something in common with Hindus and Muslims? Chuck Ramkissoon is going to make it happen. With the New York Cricket Club, we could start a whole new chapter in US history. Why not? Why not say so if it's true? Why hold back? I'm going to open your eyes. (204)

Following his motto "think fantastic," Chuck's aim is to offer a visionary instrumentalisation of cricket to foster a redefinition of national identity so that, instead of reproducing in practice an inherently discriminatory ethos, it becomes a more inclusive sense of collective identity. As Chuck suggests, the final goal is not to choose one or the other, cricket or baseball, but to include both, just as Henry Chadwick, the first to write the rules of baseball, did:

What's interesting about this guy [...] is he was a cricket nut, too. He didn't think it was America's fate, or America's national character, or what have you, to play baseball. He played cricket and baseball. They were totally compatible as far as he was concerned. He didn't see them as a fork in the road. (202--203)

However, playing in this culture of difference requires a fundamental change of deeply ingrained practices and habits, as Hans' case testifies. In the first games of cricket Hans plays with his Staten Island team, many years since he played cricket during childhood and early adolescence in his native Netherlands, Hans realises that his old batting habits combined with his

\footnotetext{
state policies and everyday patterns of engagement" (Nadine Naber, "Introduction," in Race and Arab Americans Before and After 9/11: From Invisible Citizens to Visible Subjects, ed. Amaney A. Jamal \& Nadine Naber, Syracuse NY: Syracuse UP, 2008: 4). In addition, a number of state policies introduced after 9/11 are regarded as limiting liberal democratic values and also contributing to the 'Othering' of Arab Muslims. Thus, for example, criticisms were levelled against the USA Patriot Act, which was signed by President George W. Bush on 26 October 2001, shortly after the $9 / 11$ attacks. The immediate aim of this act was to prevent future terrorist attacks in the United States and abroad. However, the act legalised a number of actions which some organisations, such as the American Civil Liberties Union, regard as going against "the civil liberties of United States citizens and residents" (US Immigration Support). The act has also been alleged to be unconstitutional (Shirin Sinnar, "Patriotic or Unconstitutional? The Mandatory Detention of Aliens under the USA Patriot Act," Stanford Law Review 55 (2003): 1446--52; Nora Graham, "Patriot Act II and Denationalization: An Unconstitutional Attempt to Revive Stripping Americans of Their Citizenship," Cleveland State Law Review 42.4 (2005): 593--621).
} 
unwillingness to adapt to the unusual characteristics of the new cricket field make him unable to fully participate in the game:

They [West Indian migrant players] could, and did, modify their batting without spiritual upheaval. I could not. More accurately, I would not change. [...] selftransformation has its limits; and my limit was reached in the peculiar matter of batting. I would stubbornly continue to bat as I always had, even if it meant the end of making runs. (46)

Hans' clinging to his old way of batting and refusal to adapt it to the new characteristics of the game in this new socio-historical context symbolically represent the difficulties faced by the individual when forced by contextual factors to redefine traditional understandings of collective and individual identity. When forced to undergo fundamental modifications to the sense of self, the individual can almost instinctively fall back on tradition and comfortably familiar ways of seeing the world as a form of self-preservation. However, as suggested in the novel by the transformation experienced by Hans, individual self-preservation is actually dependent upon the realisation of the need to adapt to the new circumstances and replace deeply ingrained practices and habits with new ones. Thus, through his experiences in New York and his relationship with Chuck, Hans is eventually able to interiorise the new sense of a hybridised collective identity propounded by Chuck, specifically focusing on post-9/11 American national identity. As Chuck suggests when referring to Henry Chadwick's views on the relationship between baseball and cricket, they should not be perceived as antagonistic, but complementary and interdependent. It is only when Hans interiorises these new ways of playing the game of American collective identity, as symbolised by cricket, that he can feel part of it and bat instinctively like an American cricketer:

When the third ball came looping down towards my legs, something unprecedented happened. Following the spin, I executed an unsightly, crooked heave. [...] The next ball, I repeated the stroke with a still freer swing. The ball flew even higher. [...] I'd hit the ball in the air like an American cricketer; and I'd done so without injury to my sense of myself. On the contrary, I felt great. And Chuck had seen it happen and, as much as he could have, had prompted it. [...] I am at last naturalised. (170)

As Hans' case exemplifies, however, the post-9/11 sense of collective identity not only experiences the reconstruction of a culture of difference within the state borders, but is also 
dependent on transnational connections. Hans' transformation symbolises the formation of sociocultural alliances that move beyond the legally regulated processes of formal citizenship, such as legal naturalisation. Whereas this formal definition of citizenship can alienate those migrants who are implicitly required to replace their earlier culture with the adopted one, ${ }^{45}$ Hans adopts a transnational definition of citizenship, which emphasises "substantive or participatory aspects of citizenship, lived practices, and identities that shape and are shaped by norms and values" in more than one place. $^{46}$

Hans' sense of collective identity, however, adds one more variant to the collective identity propounded by Chuck. Whereas Chuck's preoccupation focuses on how to redefine American national identity from the margins created within America by non-liberal discursive practices, Hans broadens traditional definitions of national identity by incorporating the inevitable transnational connections that are fostered by current processes of globalisation, and which often make the transnational migrants develop "transnational social spaces and multi-local affiliations." 47 The development of the multi-local affiliations, with personal attachments to New York, London, and the Netherlands, which Hans has achieved in the United States leads him, on his return to London and after his eventual reconciliation with his wife, to reject the limitations imposed by reductive definitions of national identity. Hans still encounters such limiting definitions amongst those who have been unable to undergo the substantive change in understandings of collective belonging that he has experienced. Consequently, in England, Hans reacts to the exclusion that is forced upon him by the small coterie of "friends who have known one another since university, if not school, days" (174) and who preclude him "by nationality from commenting on any place other than Holland" (175). Thus, as opposed to traditional forms of collective identity, which tie the individual to a specific locality and shared culture, past, and traditions, Hans has developed a number of transnational imaginative and emotional ties that have led him to what Alison Blunt terms a "respatialization," rather than deterritorialisation, of identity. $^{48}$

45 See Coutin, "Cultural Logics of Belonging and Movement," for an analysis of how the process of naturalisation in the United States implicitly requires migrants to assimilate to their host country by leaving behind their past cultural and national allegiances.

46 Alison Blunt, "Cultural Geographies of Migration: Mobility, Transnationality, and Diaspora," Progress in Human Geography 31.5 (2007): 688.

$47 \quad$ Roger Rouse, "Questions of Identity: Personhood and Collectivity in Transnational Migration to the United States," Critique of Anthropology 15.4 (1995): 355.

$48 \quad$ Blunt, "Cultural Geographies of Migration," 688. 
Hans' multi-local identity has been fostered by the transnationalism facilitated by globalisation, and Hans is one of the privileged transnational migrants. ${ }^{49}$ Thus, he can easily move jobs between continents without leaving his company, thanks to the transnational expansion of the economy which has allowed his company to have offices in different states around the world. He has also benefitted from the "new technologies of communication and transportation [that] allow migrants to sustain more frequent, less expensive, and more intimate connections than before," ${ }^{, 50}$ since this allows him, on a temporary basis, to commute transatlantically when his wife decides to move back to London. However, this constant movement between continents does not promote a rootless deterritorialisation of identity, as Renshon argues. ${ }^{51}$ Rather, the social participation and emotional relations that cricket allows Hans to establish is what makes him respatialise his sense of belonging. His link to the Netherlands is not established because of his identification with a shared national tradition, but through his memories of playing cricket as a young boy, with his mother sitting by the side of the field. Similarly, his attachment to New York -- what he calls "the nativity [that] New York encourages even its most fleeting visitor to imagine for himself" (175) -- is attained through the emotional attachments and the sense of social inclusion he experiences through cricket. Transnational connections translate old national allegiances limited to the borders of the nationstate into a sense of translocality characterised by a multiplicity of local ties promoted by participatory forms of citizenship, and which Ulrike Freitag and Achim von Oppen define as "the sum of phenomena which result from a multitude of circulations and transfers. It designates the outcome of concrete movements of people, goods, ideas, and symbols which span spatial distances and cross boundaries, be they geographical, cultural, or political." ${ }^{, 52}$ As Hans' use of

49 Hans' socio-economic circumstances place him among the elite of transnational migrants, as opposed to labour migrants who, with their maintenance of strong transnational ties with their countries of origin, contribute to contemporary definitions of a heterogeneous transnational migration in the American context. Although O'Neill's text shows awareness of the class differences between Hans and the labour migrants whom he encounters in the cricket pitch, the novel emphasises the role that cricket plays in bringing these different forms of migration into a dialogical relationship to redefine a sense of national identity. The setting for this redefinition is the cricket pitch, which symbolically functions as a Third Space of enunciation (Homi K. Bhabha, The Location of Culture, London: Routledge, 1994: 54), where a new national identity is reconstructed in the post-9/11 context, avoiding binary oppositions fostered by the conservative turn that followed in the aftermath of the terrorist attacks on 11 September. Peggy Levitt, Josh DeWind \& Steven Vertovec, "International Perspectives on Transnational Migration: An Introduction," International Migration Review 37.3 (2003): 569.

$51 \quad$ Renshon, The 50\% American, 73.

$52 \quad$ Ulrike Freitag \& Achim von Oppen, "Introduction: Translocality: An Approach to Connection and Transfer in Area Studies," in Translocality: The Study of Globalising Processes from a Southern Perspective, ed. Ulrike Freitag \& Achim von Oppen (Leiden: Brill, 2010): 5. 
Google Earth from his house in London to revisit New York and the cricket field, now in decay after Chuck's death, symbolically suggests, contemporary globalisation and transnationalism foster a respatialisation of identities that include the local, the global, and the translocal:

I fall again, as low as I can. There's Chuck's field. It is brown -- the grass has burned -- but it is still there. [...] with a single brush on the touchpad I flee upward into the atmosphere and at once have in my sights the physical planet, submarine wrinkles and all -- have the option, if so moved, to go anywhere. [...] There is no sign of nations, no sense of the work of man. The USA as such is nowhere to be seen. (244)

Hans realises that contemporary economic, technological, and socio-political developments have necessarily modified former definitions of national belonging. According to Faruk Patel, a millionaire whom Chuck had supposedly convinced to fund his cricket project, Chuck's mistake was to think just within the limits of the nation-state borders. As Faruk claims, "There is a limit to what Americans understand. The limit is cricket. [...]. My idea was different. My idea was you don't need America. Why would you? You have the TV, internet markets in India, in England. These days that's plenty. America? Not relevant" (243). However, Hans' transformation through his association with Chuck shows that the national element is not irrelevant, as Faruk suggests. In the contemporary transnational context, as Hans' respatialisation of individual identity through his friendship with Chuck implies, collective identity needs to be translated so as to include the local, the global, and the translocal.

O'Neill's novel proposes a revision of traditional definitions of national identity partly achieved through his literary reaccentuation of Fitzgerald's The Great Gatsby. Whereas in Fitzgerald's twentieth-century American classic readers symbolically board the "boats against the current, borne back ceaselessly into that past" ${ }^{\$ 53}$ of an American ethnocultural ideal, Netherland offers a redefinition of collective identity that is woven through the combination of local, global, and translocal connections. Globalisation, transnationalism, and the aftermath of 9/11 have caused diverse reactions. On the one hand, there has been a conservative turn towards an ethnocultural Americanism, similar to the one experienced in America of the 1920s and 1930s, with implicit and explicit limitations on the individual freedom of its citizens. On the other hand, this has also elicited a re-examination of what constitutes American national identity in an attempt to overcome the limitations of formal aspects of citizenship provoked by the

$53 \quad$ Fitzgerald, The Great Gatsby, 188. 
contemporary context. As O'Neill's text adumbrates, the adoption of what Gray regards as a form of multicultural criticism is not sufficient -- a fact symbolised by Chuck's demise and the death of his cricketing project. Faruk's radical intimation that the nation is dead, however, is not a realistic solution either. As Hans' case demonstrates, participation in local social practices and local cultural meanings enable the individual to establish social relations and emotional ties. The contemporary transnational turn allows the individual to respatialise a sense of place and develop a sense of identity defined by a network of multi-local affiliations. In this manner, the transnational migrant adds a new dimension to both ethnocultural and multicultural definitions of national belonging, extending the ties beyond the political boundaries and forcing a redefinition of formal and participatory citizenship. To the question that O'Neill poses at the close of his review of C.L.R. James's Beyond a Boundary, "what do they know of America who only America know?," Netherland implicitly advances the answer that it is necessary to include those who know of both America and beyond in order to begin to intuit what contemporary transnational America is.

\section{Works Cited}

Bacon, Katie. "The Great Irish-Dutch-American Novel," The Atlantic (2008), http://www.theatlantic.com (accessed 25 February 2011).

Bakhtin, Mikhail. "Discourse in the Novel," in The Dialogic Imagination: Four Essays by Mikhail Bakhtin, tr. Caryl Emerson \& Michael Holquist (Austin: U of Texas P, 1981): 259-422.

Bhabha, Homi K. The Location of Culture (London: Routledge, 1994).

---. "Making Difference: Homi K. Bhabha on the Legacy of the Culture Wars -- Writing the '80s," Artforum International (2003), http://www.thefreelibrary.com (accessed 9 October 2011).

Blunt, Alison. "Cultural Geographies of Migration: Mobility, Transnationality, and Diaspora," Progress in Human Geography 31.5 (2007): 684--94.

Bryan, Jennifer. "Terror Town Jersey City: Cultural Trauma, Conflict, and Community after 9/11," paper delivered at the American Sociological Association (2007), http://www.allacademic.com/meta/p184715_index.html (accessed 17 January 2011).

Castles, Stephen \& Alastair Davidson. Citizenship and Migration: Globalization and the Politics of Belonging (New York: Routledge, 2000).

Coutin, Susan Bibler. "Cultural Logics of Belonging and Movement: Transnationalism, Naturalization, and U.S. Immigration Politics," American Ethnologist 30.4 (2003): 508--26.

Crockatt, Richard. America Embattled: 9/11, Anti-Americanism and the Global Order (London: Routledge, 2002).

Decker, Jeffrey Louis. "Gatsby's Pristine Dream: The Diminishment of the Self-Made Man in the Tribal Twenties," NOVEL: A Forum on Fiction 28.1 (1994): 52--71. 
Delanty, Gerard. "Beyond the Nation-State: National Identity and Citizenship in a Multicultural Society - A Response to Rex," Sociological Research Online 1.3 (1996): n.p, http://www.socresonline.org.uk/1/3/1.html (accessed 9 October 2011).

Dudziak, Mary L., ed. September 11 in History: A Wathershed Moment? (Durham NC: Duke UP, 2003).

Fitzgerald, F. Scott. The Great Gatsby (1925; Harmondsworth: Penguin, 1994).

Freitag, Ulrike \& Achim von Oppen. "Introduction: Translocality: An Approach to Connection and Transfer in Area Studies," in Translocality: The Study of Globalising Processes from a Southern Perspective, ed. Ulrike Freitag \& Achim von Oppen (Leiden: Brill, 2010).

Goldsmith, Meredith. "White Skin, White Mask: Passing, Posing, and Performing in The Great Gatsby," Modern Fiction Studies 49.3 (2003): 443--68.

Graham, Nora. "Patriot Act II and Denationalization: An Unconstitutional Attempt to Revive Stripping Americans of Their Citizenship," Cleveland State Law Review 42.4 (2005): 593-621.

Gray, Richard. After the Fall: American Literature since 9/11 (Malden MA: Wiley, 2011).

---. "Open Doors, Closed Minds: American Prose Writing at a Time of Crisis," American Literary History 21.1 (2009): 128--48.

Hardt, Michael \& Antonio Negri. Empire (Cambridge MA: Harvard UP, 2000).

Huddart, David. Homi K. Bhabha (London: Routledge, 2006).

Joppke, Christian. Challenge to the Nation-State: Immigration in Western Europe and the United States (Oxford: Oxford UP, 1998).

---. Citizenship and Immigration (Cambridge: Polity, 2010).

---. Immigration and the Nation-State: The United States, Germany, and Great Britain (Oxford: Oxford UP, 1999).

Kakutani, Michiko. "Post-9/11, a New York of Gatsby-Size Dreams and Loss," The New York Times (16 May 2008), http://www.nytimes.com/2008/05/16/books/16book.html (accessed 12 February 2011).

Kaufman, Jason \& Orlando Patterson. "Cross-National Cultural Diffusion: The Global Spread of Cricket," American Sociological Review 70.1 (2005): 82--110.

Koopmans, Ruud \& Paul Statham. "Challenging the Liberal Nation-State? Postnationalism, Multiculturalism, and the Collective Claims Making of Migrants and Ethnic Minorities in Britain and Germany," American Journal of Sociology 105.3 (1999): 652--96.

Levitt, Peggy, Josh DeWind \& Steven Vertovec. "International Perspectives on Transnational Migration: An Introduction," International Migration Review 37.3 (2003): 565--75.

Michaels, Walter Ben. Our America: Nativism, Modernism, Pluralism (Durham NC: Duke UP, 1995).

Naber, Nadine. "Introduction," in Race and Arab Americans Before and After 9/11: From Invisible Citizens to Visible Subjects, ed. Amaney A. Jamal \& Nadine Naber (Syracuse NY: Syracuse UP, 2008): 1--45.

Nies, Betsy L. Eugenic Fantasies: Racial Ideology in the Literature and Popular Culture of the 1920s (New York: Routledge, 2002).

O'Kihiro, Gary Y. Margins and Mainstreams: Asians in American History and Culture (London: Routledge, 1994).

O'Neill, Joseph. "Bowling Alone," review of Beyond a Boundary by C.L.R. James, The Atlantic Monthly (11 September 2007), http://www.powells.com/review/2007_09_11.html (accessed 13 February 2011). 
- - -. Netherland (2008; London: Harper Perennial, 2009).

Ornstein, Robert. "Scott Fitzgerald's Fable of East and West," College English 18.3 (1956): 139$-43$.

"Profile: Joseph O'Neill," Times Online (31 May 2009), http://www.timesonline.co.uk, (accessed 1 October 2010).

Renshon, Stanley A. The 50\% American: Immigration and National Identity in an Age of Terror (Washington D.C.: Georgetown UP, 2005).

Rothberg, Michael. "A Failure of the Imagination: Diagnosing the Post-9/11 Novel: A Response to Richard Gray," American Literary History 21.1 (2009): 152--58.

Rouse, Roger. "Questions of Identity: Personhood and Collectivity in Transnational Migration to the United States," Critique of Anthropology 15.4 (1995): 351--80.

Rubin, Derek \& Jaap Verheul. American Multiculturalism After 9/11: Transatlantic Perspectives (Amsterdam: Amsterdam UP, 2009).

Rushdie, Salman / ICA Video (Northbrook, IL: Roland Collection of Films on Art, BBC, 1989).

Schreier, Benjamin. "Desire's Second Act: 'Race' and The Great Gatsby's Cynical Americanism," Twentieth Century Literature 53.2 (2007): 153--81.

Sinnar, Shirin. "Patriotic or Unconstitutional? The Mandatory Detention of Aliens under the USA Patriot Act," Stanford Law Review 55 (2003): 1446--52.

Smith, Rogers M. "The 'American Creed' and American Identity: The Limits of Liberal Citizenship in the United States," The Western Political Quarterly 41.2 (1988): 225--51.

Soysal, Yasemin Nuhoglu. Limits of Ctizenship: Migrants and Postnational Membership in Europe (Chicago: U of Chicago P, 1995).

Spalding, Albert G. America's National Game (1911. Lincoln: U of Nebraska P, 1992).

Thompson, Carlyle Van. The Tragic Black Buck: Racial Masquerading in the American Literary Imagination (New York: Peter Lang, 2004).

US Immigration Support. "The Patriot Act and US Immigration," US Immigration Support (2010), http://www.usimmigrationsupport.org/patriot-act.html (accessed 3 March 2011).

Versluys, Kristiaan. Out of the Blue: September 11 and the Novel (New York: Columbia UP, 2009).

Wagg, Stephen, ed. Cricket and National Identity in the Postcolonial Age: Following On (London: Routledge, 2005).

Washington, Bryan R. The Politics of Exile: Ideology in Henry James, F. Scott Fitzgerald, and James Baldwin (Boston MA: Northeastern UP, 1995).

Westphal, Sebastian J. American National Identity After September 11: Post-9/11 Experience as Mirror Narrative (Berlin: WVB, Wissentschaflicher Verlag Berlin, 2007).

Will, Barbara. "The Great Gatsby and the Obscene Word," College Literature 32.4 (2005): 125-44 . 


\section{DISCLAIMER}

This essay is the author's post-print version. Please note that pagination does not correspond with the printed version, whose full bibliographic reference is as follows:

Zamorano Llena, Carmen. "Transnational Movements and the Limits of Citizenship: Redefinitions of National Belonging in Joseph O'Neill's Netherland". Transcultural Identities in Contemporary Literature. Eds. Irene Gilsenan Nordin, Julie Hansen, and Carmen Zamorano Llena. Amsterdam: Rodopi, 2013. ISBN: 978-90-420-3735-9.

Link to the publisher's website for information on this collection of essays: http://www.rodopi.nl/senj.asp?Bookld=CC+167 